\title{
Mathematical Justification Studies in Mathematics Education: An Evaluation of Studies between 2007 and 2016
}

\author{
Yasemin Yilmaz ${ }^{1}$, Ülkü Ayvaz ${ }^{1}$, Nazan Mersin $^{1}$, Soner Durmuș ${ }^{1 *}$ and Hakan Yaman ${ }^{1}$ \\ ${ }^{1}$ Department of Mathematics and Science Education, Faculty of Education, Bolu Abant Izzet Baysal University, Turkey \\ *Corresponding author: sonerdurmus@gmail.com
}

\section{ARTICLE HISTORY}

Received : 8 February 2019

Revised : 12 June 2019

Accepted : 15 September 2019

\section{KEYWORDS}

Justification Mathematical; Mathematics Education; Evaluation of Studies;

\begin{abstract}
In this study, it was aimed to evaluate the mathematical justification studies in mathematics education between 2007 and 2016. In the study, 31 theses and articles about mathematical justification in mathematics education were analyzed by means of determined databases. In the literature review, the studies were classified according to the method, the study group, the mathematics subject, and the time frame of ten years. As a result of study, mathematical justification studies in mathematics education were carried out mostly in 2009, 2010 and 2016. As a study group, examined studies are composed mostly of students. As a method, qualitative method was used mostly. The tasks related to justification at three different levels of education were included. According to primary, middle and high school levels, the most common areas of learning for which mathematical justification tasks take place are numbers and operations, algebra and numbers and algebra, respectively.
\end{abstract}

This is an open access article under the CC-BY-SA license.

\section{INTRODUCTION}

Justification, in a broad sense, is defined as the actions students take to explain to others and themselves when they encounter a situation, what they see, what they do, what they think and why they do it (Hershkowitz, 2014, p. 544). For Kidron and Dreyfus (2010), justification is a central and important component of mathematical reasoning. They also emphasize that students must constantly extend their knowledge and build new knowledge in the process of justification of a mathematical phenomenon. Staples, Bartlo and Thanheiser (2012), who see justification as a practice of basing their mathematical reasoning, have defined this concept as an argument that demonstrates or refutes the validity of a claim that uses accepted expressions and mathematical forms of reasoning. They have stated that justification as a learning practice improves students' understanding of mathematics and increases their competence in doing mathematics. Therefore, they described justification as a tool for learning and doing mathematics. According to Valero's (2014, p. 485) study of mathematics education from a different perspective, mathematics education was in the interest of teachers and researchers in the 1980 s while the transition from the nineteenth century to the twentieth century has been a time for mathematics to be incorporated into national education systems all around the world. In the transition period from the twentieth century to the twenty-first century, that is to say nowadays, justification which has an important role in mathematics has drawn attention to the fact that it is time to focus on the education system at all levels.

Mathematical justification is used to explain and convince others this idea (Lo, Grant \& Flowers, 2004).
Mathematical justification makes it meaningful to improve the ability to speak and use mathematical language. In this respect, mathematical language is a social language and mathematical justification is a social art, and then community is needed to perform this art (Tymoczko, 1986). Creating a mathematical justification involves the development of an argument formed by the community's shared knowledge (Simon \& Blume, 1996). Explanation and justification will encourage students to develop their own solutions in a democratic classroom environment to tell their solutions to others or discuss someone else's solutions. As students develop their own solutions, they can explicitly observe and correct their mistakes (Polat, 2015). In National Council of Teachers of Mathematics (NCTM, 2000) report, the importance of justification from the prekindergarten to grade 12 was given throughout the standards. At very early ages (Pre-K-2) students should have experiences that will help them develop both clear and precise thought processes. This development of reasoning is related to the students' language development. It also depends on their ability to explain their reasoning. Teachers should encourage students to make assumptions and justify their thoughts with experimental or reasonable arguments. Here, teachers need to develop ways of justifying that the students can reach and that step by step unify the mathematical features and relationships (pp. 125-126)

Students in grades 3-5 should make and investigate conjectures about mathematical relationships, and make mathematical arguments based on their work. They need to know that making conjectures and trying to justify them is an expected feature of the students' mathematical activity. Justification have a number of meanings for students in grades 
3-5. On the other hand, as they have more experimentation by climbing up these class levels and making mathematical arguments, they should base their arguments on the analysis of properties, structures and relationships (p. 191).

Mathematics should be meaningful to students, therefore they need to see it as logical and reasoned. Their experience at school should help them understand the processes they use and explain the patterns they observe. So this helps them develop deeper understanding of mathematics. Opportunities for mathematical reasoning and proof surround the high school curriculum (Grades 9-12). Students will understand the value of mathematical justification entirely in mathematical content. So students should develop a repertoire of increasingly advanced methods of reasoning and proof in high school ( $\mathrm{p}$. 342).

As much it plays an important role in language development, justification is an important component in communication which is one of the other standards (Grades 6-8). Using written and oral communication in mathematics, teachers should provide opportunities for their students. These include justifying students' conjectures, criticizing justifications, reflecting the student's own understanding and seeing others' ideas (p. 272).

This research is based on the evaluation of the studies carried out during the ten years period between 2007 and 2016 in the national and international field on the issue of justification in mathematics education.

\section{METHOD}

This research is a descriptive study aiming to describe justification studies in mathematics education. Data collection, analysis and interpretation were carried out from the perspective of qualitative research, and document review model was used because the research was conducted based on literature review.

\subsection{Data Collection Tool}

The thesis and the articles that had been published between the related years have taken under review by using ULAKBIM, Council of Higher Education (YOK) theses center, ERIC, Taylor and Francis, JSTOR and Web of Science databases. Using the specified databases, in the national and international fields "justify", "justification" and "mathematics education" keywords have been searched together, and "mathematical justification" has been searched alone. In accordance with the classification criteria in this research, a total of 31 studies was found in the reviewed literatures implemented with these keywords.

\subsection{Data Analysis}

In the evaluation of the data, content analysis technique was used. Content analysis is to combine similar data within the framework of specific concepts and themes, and to interpret them in a way that the reader can understand (Yildirim \& Şimşek, 2013).

Obtained 31 studies were analyzed in 4 different categories. Some of the studies in the literature have been used to construct these categories. Ulutass and Ubuz (2008) examined the articles published in 4 different educational science journals between 2000 and 2006 in mathematics education. These studies have been categorized according to the language of the study, the types of research, sampling, research titles, mathematics titles, methods, data collection techniques, author's institutions and region applied. Çiltaş, Güler and Sözbilir (2012), examined mathematics education research conducted between 1987 and 2009 in Turkey with the content analysis method. In order to get answers to the research questions, the determined articles went to investigate within the scope of the year, the field and subject studied, the research method used, the data collection tools, the sample and size of the studies, and data analysis methods. Yalçınkaya and Özkan (2012) categorized the articles related to alternative methods of mathematics teaching published between 2000 and 2011. Their categories were education faculties, research methods and data collection techniques, years and their distribution in terms of the topics. Yenilmez and Sölpük (2014) examined the theses related to the mathematics curriculum between 2004 and 2013 by classifying them according to the graduate level (master and doctorate), class level, topic, study group, method and model of research. Yaşar and Papatğa (2015) studied the theses of graduate schools for elementary school mathematics courses. Theses were classified according to 11 different categories. These categories include; graduate level, prepared by the university, department of the university, the names of the consultants undertaking the responsibility of the executive, the year they were prepared, the grade level applied, the selected subject area, the selected subject, the research method, data collection techniques and data analysis method. Considering the above studies, the categories used in this research are: the year, study group, methodology and mathematics subjects to which they belong.

\section{RESULTS AND DISCUSSION}

In this section, it was given place to the examined studies' distributions according to their years, study groups, methods and mathematics subjects. A total of 31 studies including 28 articles published in the national and international field and 3 theses published in the national field were examined. The distributions of the studies according to the specified criteria are presented in the following tables with frequency and percentages.

A 10-year framework of justification studies have been established in mathematics education and the distribution of these studies by years was presented in Table 1 .

Table 1. Distribution of Studies by Years

\begin{tabular}{lcc}
\hline Year & f & $\%$ \\
\hline 2007 & 2 & 6,45 \\
2008 & 1 & 3,23 \\
2009 & 5 & 16,13 \\
2010 & 5 & 16,13 \\
2011 & 0 & 0,00 \\
2012 & 4 & 12,90 \\
2013 & 4 & 12,90 \\
2014 & 3 & 9,68 \\
2015 & 2 & 6,45 \\
2016 & 5 & 16,13 \\
\hline
\end{tabular}

When Table 1 is examined, mathematical justification studies in mathematics education were carried out mostly in 2009, 2010 and 2016. The number of studies in these years is equal in each. 15 of 31 studies were performed in these years. In addition, four studies were carried out in 2012 and 2013, two in 2007 and 2015 in each. Also there are three studies in 2014 and 
one in 2008. On the other hand, no study was done in 2011.

The distribution of the studies in terms of their study groups was presented in Table 2 .

Table 2. Distribution of Studies According to the Study Group

\begin{tabular}{lcc}
\hline \multicolumn{1}{c}{ Study Group } & $\mathrm{f}$ & $\%$ \\
\hline Student & 16 & 51,61 \\
Pre-service teacher & 6 & 19,35 \\
Teacher & 5 & 16,13 \\
Teacher and student & 2 & 6,45 \\
Teacher and pre-service teacher & 1 & 3,23 \\
Pre-service teacher, teacher and & 1 & 3,23 \\
teacher educator & & \\
\hline
\end{tabular}

According to Table 2, it is seen that the study group in mathematical justification studies is composed mostly of students. 11 of 16 studies include ranging from 6 to 8 th grade students at middle school level. One of 16 studies is with the 2nd grade students and one is in the year 9 and 10 children. Also, it was revealed that one of these studies was performed with the children years of 3 and 4 . On the other hand, six studies' study group is composed of pre-service teachers. There are only 5 studies performed with teachers. 3 of these studies were performed with high school mathematics teachers and 2 with middle school mathematics teachers. Moreover, Table 2 shows that there are four studies which including at least two different groups of participants, such as teachers, students, pre-service teachers, and teacher educators.

The distribution of the studies in terms of their methods was presented in Table 3.

Table 3. Distribution of Studies According to Their Methods

\begin{tabular}{ccc}
\hline Method & $\mathrm{f}$ & $\%$ \\
\hline Qualitative & 22 & 70,97 \\
Quantitative & 5 & 16,13 \\
Mixed & 4 & 12,90 \\
\hline
\end{tabular}

According to Table 3 , it is seen that the mathematical justification studies are more qualitative. 22 of the 31 studies were based on qualitative research methods, while in 5 of 31 studies were used quantitative research methods. On the other hand, mixed research has been used in only four studies.

Another category of the studies was the mathematics subject to which they belong. Here the subjects are classified according to their education level. Rather than giving them the individual place of the relevant mathematics subjects, they are placed in the relevant learning areas. A total of 42 tasks have been identified that address mathematical justification and fall into different subjects and learning areas. The distribution of the studies in terms of the related mathematics subjects was presented in Table 4.

Table 4. Distribution of the Tasks According to the Mathematics Subjects

\begin{tabular}{|c|c|c|c|}
\hline Level & Learning Area & $\mathbf{f}$ & $\%$ \\
\hline Primary & Numbers and operations & 3 & 75 \\
\hline \multirow[t]{3}{*}{ school } & Measurement & 1 & 25 \\
\hline & Total & 4 & 100 \\
\hline & Numbers and operations & 7 & 28 \\
\hline \multirow[t]{2}{*}{$\begin{array}{l}\text { Middle } \\
\text { school }\end{array}$} & $\begin{array}{l}\text { Geometry and } \\
\text { measurement }\end{array}$ & 8 & 32 \\
\hline & Algebra & 9 & 36 \\
\hline
\end{tabular}

\begin{tabular}{cccc}
\hline & Probability & 1 & 4 \\
& Total & 25 & 100 \\
\multirow{4}{*}{ High school } & Numbers and algebra & 8 & 61,54 \\
Geometry & 4 & 30,77 \\
& $\begin{array}{c}\text { Data, counting and } \\
\text { probability }\end{array}$ & 1 & 7,69 \\
& Total & 13 & 100 \\
\hline
\end{tabular}

When Table 4 is examined, the tasks related to mathematical justification were more frequently given in "numbers and operations" and "numbers and algebra" learning areas at primary and high school levels, respectively. This has corresponded to the learning area of "algebra" in the middle school. In both middle and high school levels, mathematical justification tasks are distributed to more learning areas than primary school level. The learning areas where the tasks take place at least are similar in the middle school and high schoold in terms of "probability" area. When examining the distribution of tasks related to justification in terms of education level, tasks are mostly at the middle school level.

In the examined studies, mathematical justification tasks were most frequently referred to in terms of "patterns". Participants in these tasks differ as students, pre-service teachers and teachers. When the patterns are taken into consideration, expressions related to concepts such as relations, generalizations, and variables have been found. Some of the other prominent tasks in the studies are in divisibility, second-order equations, trigonometry, percentage, linear function, etc. It has also been seen that some tasks are related to rational numbers, fractions, complex numbers, angle, perimeter, derivative, and so on. It is seen that in a study carried out with younger children such as primary school level, tasks generally focused on the topics of addition, subtraction, place value, measurement. An open-ended problem involving the use of even and odd numbers' properties in which the children could have the opportunity to test conjectures and reach generalizations was used in another study.

\subsection{Discussion}

This study aims to evaluate the mathematical justification studies in mathematics between 2007 and 2016. In this study, 31 theses and articles about mathematical justification in mathematics education were analyzed according to the year, study group, methodology and mathematics subjects to which they belong.

As a result of the research, justification studies in mathematics education were most frequently carried out in 2009, 2010 and 2016. While it is not possible to generalize together, it can be said that the studies on justification have increased relatively in comparison with the years that follow. In the reviewed studies it is seen that their study group mostly comprises of students and qualitative research is frequently adopted as a method. At this point, it might have been desirabled to reveal the ideas that reflect the processes of thinking than the solutions that students perform in given tasks. Because reasoning strategies such as assumption, justification and interpretation constitute the characteristic of doing mathematics in thinking processes (Henningsen \& Stein, 1997).

It is seen that justification studies are more prevalent in tasks in learning areas of numbers and operations in primary school wheras in algebra is more emphasized at the middle and 
high school level in terms of becoming meanigful. Based on Dolev and Even's (2013) study, it can be said that algebra as an essence of mathematics, it is an important branch on research, exploration, problem solving and generating mathematical conjectures, together with proof, justification and explanation. Similarly, as we progress to higher class levels such as high school, it is thought that there will be a deeper understanding of mathematics through reasoning and proof (NCTM, 2000). From this point of view, it can be said that students at these levels need to run more justifications.

This research has some limitations. One of them justification studies in mathematics education have been examined according to the mentioned six databases. An another limitation is that these studies are classified into only four categories. The study to be done by expanding these criteria and categories can be dealt with in more detail.

\section{REFERENCES}

Acevedo Nistal, A., Van Dooren, W., \& Verschaffel, L. (2013). Students' reported justifications for their representational choices in linear function problems: an interview study. Educational Studies, 39(1), 104-117.

Bieda, K. N. (2010). Enacting proof-related tasks in middle school mathematics: Challenges and opportunities. Journal for Research in Mathematics Education, 41(4), 351-382.

Bostic, J. D. (2016). Fostering Justification: A Case Study of Preservice Teachers, Proof-Related Tasks, and Manipulatives. Journal of Mathematics Education at Teachers College, 7(1), 35-43.

Brodie, K. (2010). Pressing dilemmas: meaning-making and justification in mathematics teaching. Journal of Curriculum Studies, 42(1), 27-50.

Ceylan, T. (2012). GeoGebra yazılım ortamında ilköğretim matematik ögrretmen adaylarının geometrik ispat biçimlerinin incelenmesi. (Yayımlanmamış Yüksek Lisans Tezi). Ankara Üniversitesi Eğitim Bilimleri Enstitüsü, Ankara.

Çiltaş, A., Güler, G., \& Sözbilir, M. (2012). Mathematics Education Research in Turkey: A Content Analysis Study. Educational Sciences: Theory and Practice, 12(1), 574-580.

Dixon, J. K., Egendoerfer, L. A., \& Clements, T. (2009). Do they really need to raise their hands? Challenging a traditional social norm in a second grade mathematics classroom. Teaching and Teacher Education, 25(8), 1067-1076.

Dolev, S. ve Even, R. (2013). Justifications and Explanations In Israeli 7th Grade Math Textbooks. International Journal of Science and Mathematics Education, May 2015, 13(Supp1 2), 309-327.

Ellis, A. B. (2007). Connections between generalizing and justifying: Students' reasoning with linear relationships. Journal for Research in Mathematics Education, 38(3), 194-229.

Flegas, K., \& Charalampos, L. (2013). Exploring logical reasoning and mathematical proof in grade 6 elementary school students. Canadian Journal of Science, Mathematics and Technology Education, 13(1), 70-89.

Guven, B., Cekmez, E., \& Karatas, I. (2010). Using empirical evidence in the process of proving: the case of Dynamic Geometry. Teaching Mathematics and its Applications: An International Journal of the IMA, 29(4), 193-207.

Hauk, S., \& Isom, M. A. (2009). Fostering college students' autonomy in written mathematical justification.
Investigations in Mathematics Learning, 2(1), 49-78.

Henningsen, M. ve Stein, M. K. (1997). Mathematical Taks and Student Cognition: Classroom- Based Factors That Support and Inhibit High-Level Mathematical Thinking and Reasoning. Journal for Research Mathematics Education, 28(5), 524-549.

Hershkowitz, R. (2014). Shape and Space - Geometry Teaching and Learning. Stephen Lerman (Ed.), Encyclopedia of Mathematics Education (pp. 542-547). Springer.

Karsenty, R., Arcavi, A., \& Hadas, N. (2007). Exploring informal mathematical products of low achievers at the secondary school level. The Journal of Mathematical Behavior, 26(2), 156-177.

Kidron, I. \& Dreyfus, T. (2010). Justification enlightenment and combining constructions of knowledge. Educational Studies in Mathematics 74(1), 75-93.

Kosyvas, G. (2016). Levels of arithmetic reasoning in solving an open-ended problem. International Journal of Mathematical Education in Science and Technology, 47(3), 356-372.

Lau, P. N. K., Singh, P., \& Hwa, T. Y. (2009). Constructing mathematics in an interactive classroom context. Educational Studies in Mathematics, 72(3), 307-324.

Leach, G., Hunter, R., \& Hunter, J. (2014). Teachers Repositioning Culturally Diverse Students as Doers and Thinkers of Mathematics. Mathematics Education Research Group of Australasia, 381-388.

Liu, Y., \& Manouchehri, A. (2013). Middle school children's mathematical reasoning and proving schemes. Investigations in Mathematics Learning, 6(1), 18-40.

Lo, J. J., Grant, T. J., \& Flowers, J. (2008). Challenges in deepening prospective teachers' understanding of multiplication through justification. Journal of Mathematics Teacher Education, 11(1), 5-22.

Löfström, E., \& Pursiainen, T. (2015). Knowledge and knowing in mathematics and pedagogy: a case study of mathematics student teachers' epistemological beliefs. Teachers and Teaching, 21(5), 527-542.

Maher, C. A., Palius, M. F., Maher, J. A., Hmelo-Silver, C. E., \& Sigley, R. (2014). Teachers can learn to attend to students' reasoning using videos as a tool. Issues in Teacher Education, 23(1), 31-47.

Matteson, S., Capraro, M. M., Capraro, R. M., \& Lincoln, Y. S. (2012). Extricating Justification Scheme Theory in Middle School Mathematical Problem Solving. Investigations in Mathematics Learning, 5(1), 38-62.

Mueller, M. F. (2009). The co-construction of arguments by middle-school students. The Journal of Mathematical Behavior, 28(2-3), 138-149.

National Council of Teachers of Mathematics [NCTM]. (2000). Principles and standards for school mathematics. Reston, VA: NCTM Publications.

Özcan, B. N. (2012). İköğretim Öğrencilerinin Geometrik Düşünme Düzeylerinin Geliştirilmesinde Bilgiyi Oluşturma Süreçlerinin İncelenmesi. (Yayımlanmamış Doktora Tezi). Dokuz Eylül Üniversitesi Eğitim Bilimleri Enstitüsü, İzmir.

Polat, M. (2015). İlköğretim 7. Sinıf Matematik Ders ve Çalışma Kitaplarındaki Açıklama ve Gerekçelendirme Gerektiren Görevlerin Öğrenme Alanlarına Göre İncelenmesi. (Yayımlanmamış Yüksek Lisans Tezi). Gaziantep Üniversitesi Eğitim Bilimleri Enstitüsü, Gaziantep.

Rott, B., \& Leuders, T. (2016). Inductive and Deductive Justification of Knowledge: Flexible Judgments 
Underneath Stable Beliefs in Teacher Education. Mathematical Thinking and Learning, 18(4), 271-286.

Sidenvall, J., Lithner, J., \& Jäder, J. (2015). Students' reasoning in mathematics textbook task-solving. International Journal of Mathematical Education in Science and Technology, 46(4), 533-552.

Simon, M. A. \& Blume, G. W. (1996). Justification in the mathematics classroom: A study of prospective elementary teachers. The Journal of Mathematical Behavior, 15(1), 3-31.

Sönmez, N. (2016). Üç boyutlu sanal öğrenme ortamlarında sosyal ve sosyomatematiksel normlarin belirlenmesi: Mathlife Örneği. (Yayımlanmamış Yüksek Lisans Tezi). Karadeniz Teknik Üniversitesi Eğitim Bilimleri Enstitüsü, Trabzon.

Staples, M. E., Bartlo, J., \& Thanheiser, E. (2012). Justification as a teaching and learning practice: Its (potential) multifacted role in middle grades mathematics classrooms. The Journal of Mathematical Behavior, 31(4), 447-462.

Stylianou, D. A. (2013). An Examination of Connections in Mathematical Processes in Students' Problem Solving: Connections between Representing and Justifying. Journal of Education and Learning, 2(2), 23-35.

Tabach, M., Barkai, R., Tsamir, P., Tirosh, D., Dreyfus, T., \& Levenson, E. (2010). Verbal justifcation-Is it a proof? secondary school teachers' perceptions. International Journal of Science and Mathematics Education, 8(6), 1071-1090.

Tabach, M., Levenson, E., Barkai, R., Tirosh, D., Tsamir, P., \& Dreyfus, T. (2010). Secondary school teachers' awareness of numerical examples as proof. Research in Mathematics Education, 12(2), 117-131.

Tymoczko, T. (1986). Making room for mathematicians in the philosophy of mathematics. The Mathematical Intelligencer, 8(3), 44-50.

Tsamir, P., Tirosh, D., Dreyfus, T., Barkai, R., \& Tabach, M. (2009). Should proof be minimal? Ms T's evaluation of secondary school students' proofs. The Journal of Mathematical Behavior, 28(1), 58-67.

Ulutaş, F. \& Ubuz, B. (2008). Matematik Eğitiminde Araştırmalar ve Eğilimler: 2000 ile 2006 Yılları Arası. İlköğretim Online, 7(3), 614-626.

Valero, P. (2014). Political Perspectives in Mathematics Education. Stephen Lerman (Ed.), Encyclopedia of Mathematics Education (pp. 484-487). Springer.

Widjaja, W. (2014, January). Year 3/4 children's forms of justification. In MERGA 2014: Curriculum in focus: research guided practice: Proceedings of the Mathematics Education Research Group of Australasia 2014 annual conference (pp. 694-697). Mathematics Education Research Group of Australasia.

Yalçınkaya, Y., \& Özkan, H. H. (2012). 2000-2011 Yilları Arasında Eğitim Fakülteleri Dergilerinde Yayımlanan Matematik Öğretimi Alternatif Yöntemleri İle İlgili Makalelerin İçerik Analizi. Süleyman Demirel Üniversitesi Sosyal Bilimler Enstitüsü Dergisi, 2(16), 31-45.

Yaşar, Ş. \& Papatğa, E. (2015). İlkokul Matematik Derslerine Yönelik Yapılan Lisansüstü Tezlerin İncelenmesi. Trakya Üniversitesi Eğitim Fakültesi Dergisi, 5(2), 113-124.

Yenilmez, K. \& Sölpük, N. (2014). Matematik Dersi Öğretim Programı İle İlgili Tezlerin İncelenmesi (2004-2013). Eğitim ve Öğretim Araştırmaları Dergisi, 3(2), 33-42.

Yıldırım, A. \& Şimşek, H. (2013). Sosyal Bilimlerde Nitel
Araştırma Yöntemleri. Ankara: Seçkin Yayıncılık.

Zeybek, Z. (2016). Pre-Service Elementary Teachers' Proof and Counterexample Conceptions. International Journal for Mathematics Teaching and Learning, 17(2). 